\title{
Pengembangan Media Matematika Virtual Berbasis Teams Game Tournament Ditinjau dari Kemampuan Pemecahan Masalah
}

\author{
Nuryadi* \\ Prodi Pendidikan Matematika, Universitas Mercu Buana Yogyakarta. \\ Jalan Wates KM 10, Sedayu, Yogyakarta 55753, Indonesia. \\ *E-mail: nuryadi@mercubuana-yogya.ac.id, Telp : +6285799909816
}

Article received : 03-01-2019, article revised : 15-02-2019, article published: 31-03-2019

DOI : $10.25273 /$ jipm.v7i2.3656

\begin{abstract}
Abstrak
Tujuan penelitian ini adalah untuk mengembangkan media pembelajaran matematika virtual berbasis teams game tournament ditinjau dari kemampuan pemecahan masalah yang valid, praktis, dan efektif. Media pembelajaran matematika virtual yang dihasilkan berbasis teams game tournament pada materi pokok bangun ruang sisi datar memuat 4 tingkatan dengan permainan Uno Beam Magic, dimana permainan ini terdapat soal-soal yang harus dikerjakan untuk naik ke level berikutnya. Prosedur pengembangan media matematika virtual menggunakan 5 tahapan yaitu analisis, perancangan, pengembangan, implementasi, dan evaluasi. Uji coba yang dilakukan meliputi ujicoba ahli/validasi ahli (expert judgement), uji coba kelompok kecil (small group try-out) dan uji coba lapangan (field try-out). Uji coba lapangan (field try-out) dilakukan pada dua kelas VIII di SMP N 1 Sedayu. Instrumen penelitian yang digunakan adalah lembar validasi, lembar penilaian kepraktisan oleh guru, lembar penilaian kepraktisan oleh siswa, dan instrumen tes keefektifan media. Analisis data dilakukan dengan mengkonversi total skor data kuantitatif yang diperoleh menjadi data kualitatif skala lima. Hasil penelitian ini menunjukkan bahwa media matematika virtual berbasis teams game tournament memenuhi kriteria valid, praktis dan efektif ditinjau dari kemampuan pemecahan masalah.
\end{abstract}

Kata Kunci: Pengembangan; Teams Game Tournament; Media Pembelajaran Matematika Virtual; Pemecahan Masalah; Uno Beam Magic.

\section{Virtual Mathematics Media Development Based Teams Game Tournament reviewed from Problem Solving Ability}

\begin{abstract}
The purpose of this research is to produce a virtual mathematics learning media based on teams game tournament in terms of valid, practical, and effective problem solving abilities. The virtual mathematics learning media generated by teams game tournament on the subject matter of building a flat side room contains four levels with the game Uno Beam Magic, where the game has problems that must be done to move up to the next level. The procedure of developing virtual mathematics media using 5 stages is analysis, design, development, implementation, and evaluation. Experiments include expert expert / expert judgment, small group try-out and field try-out. Field trials (field try-outs) were conducted in two classes VIII in SMP N 1 Sedayu. The research instruments used are validation sheet, practicality assessment sheet by teacher, student's practicality score sheet, and media effectiveness test instrument. Data analysis is done by converting the total score of quantitative data obtained into qualitative data scale five. The results of this study indicate that the virtual mathematical media based on teams game tournament meets the valid, practical and effective criteria in terms of problem solving abilities.
\end{abstract}

Keywords: Development; Teams Game Tournament Virtual Mathematics Learning Media; Problem Solving; Uno Beam Magic. 


\section{PENDAHULUAN}

Dalam kurikulum 2013 disebutkan bahwa salah satu untuk menghadapi tantangan perkembangan dan teknologi serta informasi diperlukan sumber daya manusia yang memiliki kemampuan hidup sebagai pribadi dan warga negara yang beriman, produktif, kreatif dan inovatif. Untuk itu, program pendidikan yang dikembangkan perlu menekankan kemampuan berpikir pada siswa khususnya siswa SMP. Pengembangan kemampuan berpikir ini dapat dilakukan melalui pembelajaran matematika.

Menurut Sugiman (2013) pembelajaran matematika yang terjadi di kelas-kelas saat ini masih cenderung pada metode penuangan pengetahuan oleh guru kepada siswanya. Secara umum guru lebih percaya diri manakala mengajarkan dengan cara memulai proses pengajaran dengan penyampaian informasi (berupa fakta, konsep, prosedur, dan terkadang juga metakognisi) dari matematika. Karena objek belajar matematika adalah abstrak, maka pelajaran yang menekankan pada pemberian informasi akan menghalangi daya abstraksi siswa. Berdasarkan uraian di atas maka sangat diperlukan strategi yang mampu melibatkan siswa secara aktif dan mendorong siswa agar termotivasi untuk belajar matematika sebelum ia memulai mengerjakan matematika.

Salah satu upaya yang bisa dilakukan adalah dengan menggunakan alat bantu komputer. Munir (2008) menge-mukakan bahwa komputer dulunya diper-gunakan hanya sebatas pengolah data (word processing) dan alat bantu bantu menghitung, namun seiring dengan kemajuan teknologi maka komputer telah bergeser dengan kemampuannya dalam mengakses atau menjalankan program-program pembelajaran yang dikemas dalam bentuk multimedia.
Komputer sudah dapat digunakan untuk membuat multimedia maupun alat peraga interaktif. Munir (2008) mengutip hasil penelitian eksperimen yang dilakukan oleh Edward, dkk yang berhasil meng-ungkapkan bahwa pembelajaran dengan menggunakan multimedia memberikan hasil yang lebih baik secara signifikan dibanding dengan pembelajaran yang menggunakan buku teks.

Geisert (1995) menjelaskan bahwa multimedia merupakan kombinasi beberapa jenis media ke dalam satu aplikasi komputer disertai aspek yang menarik minat siswa, seperti gambar, animasi, warna, grafik digital, dan suara. Namun demikian hanya 20-25\% yang memenuhi syarat dan layak digunakan untuk keperluan pen-didikan (Munir, 2008). Fakta seperti ini merupakan suatu tantangan yang perlu disikapi dengan segera untuk mengembang-kan media pembelajaran virtual menarik berbasis Teams Game Tournament (TGT). Keunggulan dalam TGT menggunakan permainan yang dapat disesuaikan dengan topik apapun. Permainan ini biasanya lebih baik daripada permainan individu, memberikan kesempatan bagi siswa untuk peduli satu sama lain dan menghindari sebuah masalah permainan individu. Jika semua siswa menggabungkan kemampuannya dalam tim, semua siswa memiliki peluang yang baik untuk sukses (Slavin, 2008). Dengan adanya permainan dan kompetisi memungkinkan siswa dapat belajar lebih rileks disamping itu dapat menumbuhkembangkan tanggungjawab, kejujuran, kepedulian, persaingan sehat dan keterlibatan siswa dalam belajar.

Pentingnya kemampuan pemecahan masalah diperkuat oleh National Council of Teacher of Mathematics (NCTM, 2000) menyatakan bahwa pemecahan masalah me- 
rupakan sarana mempelajari ide matematika dan terampil matematika. Namun demikian, kenyataan di lapangan menunjukkan bahwa kegiatan pemecahan masalah dalam proses pembelajaran belum dijadikan sebagai kegiatan yang utama. Padahal di negara-negara maju, kegiatan ini sudah menjadi inti dari kegiatan pembelajaran matematika di sekolahan. Belum maksimalnya kemampuan pemecahan masalah matematika tidak hanya disebabkan oleh sifat matematika yang abstrak tersebut tetapi juga tidak terlepas dari proses pembelajaran matematika.

Berdasarkan salah satu tujuan pembelajaran matematika di atas adalah siswa mampu pemecahkan suatu masalah. Pemecahan masalah merupakan bagian dari pembelajaran matematika yang sangat penting, karena dalam proses pembelajaran, siswa dimungkinkan menggunakan pengetahuan serta keterampilan yang sudah dimilikinya untuk diterapkan pada pemecahan masalah yang bersifat tidak rutin. Kegiatan ini dilakukan dengan menerapkan aturan, penemuan pola, penggeneralisasian, dan komunikasi matematika yang baik sehingga kemampuan siswa dalam memecahkan masalah membutuhkan kemampuan-kemampuan yang lain, seperti memahami konsep matematika, pemodelan matematika, penalaran dan komunikasi dalam matematika. Sebagaimana tercantum dalam kurikulum matematika sekolah yang mana tujuan diberikannya matematika antara lain agar siswa mampu menghadapi perubahan keadaan dunia yang selalu berkembang, melalui bertindak dengan dasar pemikiran yang logis, rasional, kritis, cermat, jujur dan efektif.

Pengembangan media pembelajaran matematika virtual berbasis TGT di sekolah dengan biaya terjangkau, namun efektif dan efisien dalam menunjang pembelajaran. Dalam penelitian sebelumnya, menurut
Nuryadi (2016), Cooperative Learning tipe TGT efektif ditinjau dari kemampuan komunikasi dan pemecahan masalah. (Nuryadi \& Khuzaini, 2016). Penelitian untuk mewujudkan media pembelajaran matematika virtual berbasis TGT ditinjau dari kemampuan pemecahan masalah ini sangat urgen untuk dilaksanakan sehingga segera memfasilitasi kegiatan pembelajaran matematika di sekolah.

Dalam pengembangan media pembelajaran matematika virtual berbasis TGT ini adalah Permainan dalam proses pembelajaran dengan pengembangan media pembelajaran virtual yang disebut Uno Beam Magic (UBM). Menurut Nurfitri (Nuryadi, 2018) mengemukakan bahwa Uno Beam Magic merupakan permainan yang digunakan sebagai media pemahaman siswa dalam pembelajaran matematika yang membuat siswa menjadi tertarik dan mudah dalam memperlajari pelajaran matematika.

Permainan ini merupakan permainan untuk melatih strategi dengan menyusun balok-balok membentuk menara, dimana setiap balok terdiri dari susunan balok dan setiap balok terdapat soal-soal tentang matematika yang membuat anak bermain sekaligus belajar pelajaran matematika. Sedangkan permainan balok itu sendiri, merupakan cikal bakal dari semua mainan edukasi, mungkin yang paling tua di dunia. Jenis dan bentuknya pun bermacam-macam, detail, dan unik.

\section{Kriteria Produk media Pembelajaran berbasis media virtual interaktif \\ Media pembelajaran yang layak di- gunakan memiliki beberapa kriteria yang harus diketahui, menurut Romi Satria Wahono (2008) ada tiga aspek kriteria produk multimedia, yaitu : (a) aspek desain pembel- ajaran; (b)Aspek rekayasa perangkat lunak;}


(c) Aspek komunikasi visual. Sedangkan menurut Lee dan Owens (2004) menyatakan bahwa multimedia yang berkualitas seharusnya memiliki tema yang berhubungan dengan pemecahan masalah, batasan interaksi dan umpan balik, batasan perlakuan video dan audio, standar desain teks, standar desain grafis, dan mengatur animasi dan efek khusus digunakan untuk mendukung tujuan pembelajaran.

Kualitas multimedia berpengaruh terhadap hasil yang ingin dicapai oleh pengguna, sehubungan dengan itu Pustekkom (2004) memaparkan bahwa kriteria kualitas multimedia ditinjau dari aspek media meliputi: (1) pemilihan jenis dan ukuran huruf; (2) pemilihan dan komposisi warna; (3) tampilan grafis, gambar, foto dan grafik; (4) kualitas video; (5) animasi, pengguna narasi; (6) daya dukung musik dan sound effec; (7) screen design; (8) penggunaan bahasa; (9) navigasi; (10) kon-sistensi tombol; (11) kemudahan meng-gunakan; (12) antisipasi kemungkinan respon siswa; (13) respon terhadap respon siswa; (14) kecepatan.

\section{METODE}

Produk yang dihasilkan dari penelitian ini berupa media pembelajaran matematika virtual berbasis TGT yaitu multimedia interaktif pada materi "Bangun Ruang Sisi Datar" untuk siswa SMP kelas VIII. Dalam penelitian pengembangan ini peneliti akan mengikuti desain pengembangan media ADDIE (Analysis, Design, Development, Implementation, Evaluation). Adapun langkahlangkah pengembangan oleh ADDIE, antara lain sebagai berikut:(1) Analisis: pada tahap ini kegiatan yang dilakukan adalah menganalisis kebutuhan dan karasteristik siswa, menganalisis kurikulum untuk menetapkan kompetensi hasil belajar, memilih dan menetapkan materi pokok yang akan dikembangkan, dan mengembangkan alat evaluasi; (2) Desain: pada tahap ini, pengembangan membuat storyboard dan flowchart;(3) Produksi: pada tahap ini dilakukan pengkemasan materi ke dalam CD sesuai storyboard yang telah dibuat; (4) Implementasi : dalam tahap ini, akan dilakukan uji coba. sebelum uji coba dilaksanakan, dilakukan review atau validasi oleh ahli materi dan ahli media terhadap produk multimedia yang dikembangkan;(5) Kemudian dilakukan uji coba dengan langkah-langkah sebagai berikut : (a) Uji coba satu lawan satu;(b) Uji coba kelompok kecil;(c) Uji coba kelompok besar/uji coba lapangan. Revisi dilakukan setiap selesai melakukan uji coba yang berdasarkan saran dan kritik dari subyek coba; dan (6) Evaluation : dalam tahap ini akan dilakukan evaluasi media pembelajaran yang telah dibuat berdasarkan hasil angket evaluasi media pembelajaran. Berdasarkan hasil evaluasi ini selanjutnya dapat diketahui karakteristik media pem-belajaran matematika virtual berbasis TGT yang diharapkan.

Nieveen (1999) mengatakan kualitas produk, pendesainan, pengembangan, dan pengevaluasian program harus memenu-hi kriteria valid, praktis, dan efektif. Untuk menggambarkan kriteria kevalidan produk pembelajaran yaitu apabila perangkat pembelajaran dapat menggambarkan kurikulum yang diharapkan atau intended, yakni kombinasi antara ideal dan formal.

Melakukan uji awal terhadap desain produk oleh ahli bidang pembelajaran matematika, guru mata pelajaran matematika, dan ahli media. Ahli materi dan pembelajaran matematika bertujuan untuk menilai kevalidan multimedia pembelajaran matematika dari aspek materi. Ahli materi dan pem- 
belajaran tersebut terdiri dari orang, yaitu : Prof. Dr. Rusgianto Heri Santoso, M.Pd selaku dosen pendidikan matematika Universitas Negeri Yogyakarta.

Selain itu, karena kevalidan produk tidak hanya hanya ditinjau dari aspek materi dan pembelajaran tetapi juga ditinjau dari aspek media. Oleh karena itu untuk menilai kevalidan produk juga ditinjau dari aspek media yang dinilai oleh ahli media. Ahli media tersebut terdiri dua orang yaitu Heru Sukoco, S.Si., M.Pd dan Jaylani Susanto, S.Kom.

Uji kelompok kecil dilakukan untuk mengetahui efektifitas desain produk. Uji coba dilakukan pada 20 orang siswa kelas VIII SMP N 1 Sedayu Kabupaten Bantul yang mewakili kelompok dengan kemampuan tinggi, sedang dan kurang. Hasil uji coba berupa desain yang praktis dari sisi penggunaan.

Uji coba dilakukan pada seluruh siswa kelas VIII SMP N 1 Sedayu Kabupaten Bantul yang terdiri dari 64 siswa yang terbagi ke dalam dua kelas. Pada saat ujicoba lapangan, guru yang melaksanakan pembelajaran adalah peneliti. Ujicoba lapangan dimaksudkan untuk menilai keefektifan dan kepraktisan produk. Penilaian kepraktisan selain dinilai oleh siswa juga dinilai oleh seorang guru matematika, yaitu Drs. Sri Joko selaku guru matematika di SMP N 1 Sedayu Kabupaten Bantul

Untuk uji kepraktisan dapat dilihat dari pendapat oleh pengguna terutama guru dan siswa yang menganggap produk yang dihasilkan mudah untuk digunakan dan juga menggambarkan proses pembelajaran yang aktual. Ini dimaksudkan adanya kekonsistenan antara intended dan perceived curriculum dan intended and operational curriculum. Jika keduanya konsisten maka produk tersebut dikatakan praktis. Berdasarkan pen- dapat di atas, maka untuk tingkat kepraktisan dalam media pembelajaran matematika virtual berbasis TGT ini ditinjau dari penilaian guru dan penilaian siswa. Untuk itu aspek kepraktisan dikaitkan yaitu dengan penilaian para pengguna (guru dan siswa) menyatakan produk yang dikembangkan mudah untuk digunakan.

Data kepraktisan multimedia pembelajaran matematika diperoleh dari penilaian guru dan siswa terhadap multimedia pembelajaran matematika. Kepraktisan multimedia pembelajaran matematika yang dikembangkan diukur berdasarkan hasil penilaian dari guru dan siswa yang menggunakan produk pada saat uji coba.

Multimedia pembelajaran matematika yang dikembangkan dikatakan praktis jika penilaian kepraktisan perangkat pembelajaran oleh guru dan siswa konsisten minimal berada pada kategori baik. Sedangkan untuk tingkat keefektifan mengacu pada kriteria ideal ketuntasan untuk masing-masing indikator adalah $75 \%$.

\section{Analisis Data}

Data yang diperoleh dari angket validasi ahli dianalisis berdasarkan langkahlangkah berikut: (1) Penilaian oleh ahli dirangkum dalam satu tabel yang disebut tabel hasil penilaian kelayakan produk; (2) Pemeriksaan terhadap setiap hasil penilaian oleh ahli; (3) Mengolah data pada masingmasing aspek yang dinilai yang meliputi: aspek kognitif Intrinsik, aspek kognitif ekstra, aspek kualitas materi matematika, aspek Syarat Didakdik, aspek Syarat Konstruksi, dan aspek Syarat Teknis; dan (4) Membuat kriteria hasil penilaian sebagaimana disajikan pada tabel kriteria berikut. Produk yang dinilai dikatakan baik 
atau valid apabila kriteria yang didapatkan adalah Baik atau Sangat Baik.

Pada penelitian pengembangan ini, peneliti memberi nilai kelayakan produk multimedia pembelajaran hasil pengembangan minimal "B" dengan katagori "Baik", sehingga hasil penilaian, baik dari ahli materi maupun ahli media dan juga siswa, jika sudah memberikan penilaian akhir (keseluruhan) dengan nilai minimal "B", maka produk multimedia pembelajaran hasil pengembangan tersebut sudah dianggap layak untuk digunakan.

\section{Teknik Analisis Data Kevalidan}

Data berupa skor penilaian dari validator yang diperoleh dalam bentuk kategori yang terdiri dari lima pilihan penilaian tentang kualitas produk media pembelajaran matematika virtual berbasis TGT yang dikembangkan, yaitu sangat baik (5), baik (4), cukup (3), kurang (2) dam sangat kurang (1). Data tersebut diubah menjadi data interval.

Penilaian ahli materi dilakukan oleh satu penilai dengan banyak item penilaian untuk ahli materi yaitu 14 item. Dengan demikian dapat diperoleh skor minimum ideal $=14$, skor maksimum ideal $=80, \quad \mathrm{i}=$ 48 dan SBi $=10,67$. Sedangkan Penilaian ahli media dilakukan oleh satu penilai dengan banyak item penilaian untuk ahli media yaitu 9 item. Dengan demikian dapat diperoleh skor minimum ideal $=9$, skor maksimum ideal $=65, \quad \mathrm{i}=39$ dan $\mathrm{SBi}=$ 8,67 . sehingga diperoleh kriteria interval sebagai berikut.

Tabel 1. Kriteria Interval Kevalidan

\begin{tabular}{|c|c|c|c|}
\hline \multicolumn{2}{|c|}{ Interval } & \multirow[b]{2}{*}{ Nilai } & \multirow[b]{2}{*}{ Kategori } \\
\hline $\begin{array}{c}\text { Kriteria } \\
\text { Materi }\end{array}$ & $\begin{array}{c}\text { Kriteria } \\
\text { Media }\end{array}$ & & \\
\hline$X>67,206$ & $X>54,606$ & $\mathrm{~A}$ & Sangat Baik \\
\hline $54,402<X \leq 67,206$ & $44,202<X \leq 54,606$ & B & Baik \\
\hline $41,598<X \leq 54,402$ & $33.798<X \leq 44,202$ & $\mathrm{C}$ & Cukup \\
\hline $28,794<X \leq 41,598$ & $23,394<X \leq 33,798$ & $\mathrm{D}$ & Kurang \\
\hline$X \leq 28,794$ & $X \leq 23,394$ & $\mathrm{E}$ & $\begin{array}{l}\text { Sangat } \\
\text { Kurang }\end{array}$ \\
\hline
\end{tabular}

Media pembelajaran matematika virtual berbasis TGT yang dihasilkan dikatakan baik jika minimal tingkat kualitas untuk masing masing kriteria yang dicapai adalah kategori baik.

\section{Teknik Analisis Data Kepraktisan}

Data kepraktisan media pembelajaran matematika virtual berbasis TGT diperoleh dari penilaian siswa terhadap media pembelajaran matematika interaktif. Kepraktisan media pembelajaran matematika virtual berbasis TGT yang dikembangkan diukur berdasarkan hasil penilaian dari siswa yang menggunakan produk pada saat uji coba. Skor penilaian yang diperoleh dari siswa dikonversikan menjadi data kualitatif skala lima.

Penilaian siswa dilakukan oleh penilai dengan banyak item penilaian untuk siswa yaitu item. Dengan demikian dapat diperoleh skor minimum ideal skor maksimum ideal dan . Sehingga, diperoleh kriteria interval sebagai berikut. 
Tabel 2. Kriteria Interval Kepraktisan

\begin{tabular}{ccc}
\hline $\begin{array}{c}\text { Kriteria } \\
\text { Materi }\end{array}$ & Nilai & Kategori \\
\hline$X>67,206$ & $\mathrm{~A}$ & Sangat Baik \\
$54,402<X \leq 67,206$ & $\mathrm{~B}$ & Baik \\
$41,598<X \leq 54,402$ & $\mathrm{C}$ & Cukup \\
$28,794<X \leq 41,598$ & $\mathrm{D}$ & Kurang \\
$X \leq 28,794$ & $\mathrm{E}$ & Sangat Kurang \\
\hline
\end{tabular}

Media pembelajaran matematika virtual berbasis TGT yang dikembangkan dikatakan praktis jika penilaian kepraktisan media pembelajaran matematika virtual berbasis TGT yang dikembangkan oleh siswa konsisten minimal tingkat kualitas untuk masing masing kriteria yang dicapai adalah kategori baik.

\section{Teknik Analisis Data Keefektifan}

Analisis terhadap keefektifan media pembelajaran matematika virtual berbasis TGT dilakukan terhadap kemampuan pemecahan masalah. Media pembelajaran yang dikembangkan dikatakan efektif jika hasil dari tes secara signifikan atau minimal skor yang dicapai menunjukkan persentase ketuntasan minimal $75 \%$.

\section{HASIL DAN PEMBAHASAN}

\section{Prosedur Pengembangan}

Pengembangan media pembelajaran matematika virtual berbasis TGT dikembangkan dengan beberapa tahapan. Adapun tahapantahapan tersebut adalah sebagai berikut:

a. Tahap I

1) Menganalisis standar kompetensi menggunakan bangun ruang sisi datar dalam pemecahan masalah yang berkaitan dengan balok, kubus, Prisma dan Limas untuk disampaikan melalui multimedia pembelajaran. Proses ini meliputi kajian materi matematika yang sesuai dengan standar isi.
2) Mengumpulkan referensi mengenai materi pokok Bangun Ruang Sisi Datar. Pemilihan standar kompetensi menggunakan BRSD dalam pemecahan masalah yang berkaitan dengan mengidentifikasi unsur, luas dan volume BRSD karena pada standar kompetensi tersebut hasil belajar siswa masih banyak yang masih dibawah KKM (hasil pra survei yang dilakukan di SMP N 1 Sedayu Bantul). Selain itu, nilai ujian nasional (UN) di SMP N 1 Sedayu pada standar kompetensi tersebut selama tiga tahun terakhir mengalami penurunan (laporan BSNP).

3) Merencanakan dan memilih jenis media pembelajaran yang akan digunakan. Multimedia pembelajaran yang dipilih yaitu berupa $\mathrm{CD}$ pembelajaran yang dapat digunakan dengan perangkat komputer. Pemilihan ini dikarenakan pengemasan dalam bentuk CD sangat efektif karena mempunyai memori yang cukup besar dan tidak mudah terhapus, selain itu multimedia pembelajaran ini dibuat menggunakan program Adobe Flash CS 5 yang penggunaannya harus menggunakan komputer.

\section{b. Tahap II}

Pembuatan multimedia pembelajaran ini membahas tentang standar kompetensi menggunakan bangun ruang sisi datar. Tahap ini merupakan desain awal pembuatan multimedia pembelajaran matematika yang dikembangkan. Desain tersebut menggambarkan alur halaman yang tersedia pada multimedia mulai dari halaman pembuka hingga halaman penutup. Pembuatan multimedia pembelajaran matematika mengacu pada desain ini. 


\section{Pembahasan}

Untuk menganalisis kevalidan produk digunakan dua data, yaitu penilaian ahli materi dan pembelajaran matematika, dan penilaian ahli media terhadap media pembelajaran matematika virtual berbasis TGT.

Tabel 3. Data Skor Kevalidan Media Pembelajaran Matematika Virtual Berbasis Teams Game Tournament

\begin{tabular}{llcc}
\multicolumn{4}{c}{ Teams Game Tournament } \\
\hline No & \multicolumn{1}{c}{ Aspek } & Skor & Kategori \\
\hline 1 & Materi dan & 60,33 & Sangat Baik \\
& $\begin{array}{l}\text { Pembelajaran } \\
\text { Matematika }\end{array}$ & & \\
\hline 2 & Media Virtual & 39,5 & Sangat Baik \\
& Berbasis TGT & & \\
\hline
\end{tabular}

Dari Tabel 3 skor yang diperoleh untuk kevalidan produk dari aspek materi dan pembelajaran matematika yaitu 60,33, dimana berada pada rentang skor di atas 56 sehingga kevalidan produk dari aspek materi dan pembelajaran matematika termasuk kategori sangat baik. sedangkan skor kevalidan yang diperoleh dari aspek media yaitu 39,5 yang berada pada rentang 36, sehingga kevalidan produk dari aspek media termasuk dalam kategori sangat baik.

Penilaian kevalidan produk dari ahli materi dan pembelajaran dan ahli media secara konsisten menyatakan sangat baik. Oleh karena itu, dari data yang diperoleh dari penilaian oleh ahli materi dan pembelajaran matematika, dan ahli media dapat disimpulkan bahwa produk yang dikembangkan yaitu berupa multimedia pembelajaran matematika dapat dinyatakan sangat valid sehingga layak digunakan.

\section{Analisis Kepraktisan Multimedia}

\section{Pembelajaran Matematika.}

Untuk mengetahui kepraktisan produk yang dikembangkan data yang digunakan adalah data tentang penilaian guru dan siswa terhadap multimedia pembelajaran matematika.
Berdasarkan lembar angket yang diberikan kepada 64 siswa dan 1 guru matematika, diperoleh data tentang penilaian siswa dan guru terhadap multimedia pembelajaran matematika seperti telah disajikan pada tabel 4 berikut.

Tabel 4. Data Skor Kepraktisan Multimedia Pembelajaran Matematika

\begin{tabular}{clcl}
\hline No & Penilai & Skor & \multicolumn{1}{c}{ Kategori } \\
\hline 1 & Siswa & 201,6 & Sangat Baik \\
\hline 2 & Guru & 3,9 & Baik \\
\hline
\end{tabular}

Dari Tabel 4 di atas skor yang diperoleh untuk kepraktisan produk berdasarkan penilaian siswa yaitu 201,6 yang berada pada rentang skor di atas 196 sehingga kepraktisan produk berdasarkan penilaian siswa termasuk kategori sangat baik. sedangkan skor kepraktisan yang diperoleh dari penilaian guru yaitu 3,9 yang berada pada rentang 3,33-4, sehingga kepraktisan produk berdasarkan penilaian guru termasuk dalam kategori baik.

Penilaian kepraktisan produk dari siswa dan guru secara konsisten menyatakan baik. Oleh karena itu, dari data yang diperoleh dari penilaian siswa dan guru dapat disimpulkan bahwa produk yang dikembangkan yaitu berupa multimedia pembelajaran matematika dapat dinyatakan praktis sehingga layak digunakan.

\section{Analisis Keefektifan Multimedia Pembel- ajaran Matematika}

Untuk mengetahui keefektifan media pembelajaran matematika virtual berbasis TGT yang dikembangkan digunakan instrumen tes kemampuan pemecahan masalah. Berdasarkan data hasil tes siswa kelas VIII, sebanyak 64 siswa diperoleh hasil analisis seperti pada tabel 5 berikut: 
Tabel 5. Analisis Data Tes kemampuan pemecahan masalah

\begin{tabular}{lcc}
\hline \multicolumn{1}{c}{ Jenis Tes } & $\begin{array}{l}\text { Jumlah siswa } \\
\text { yang tuntas }\end{array}$ & Persentase \\
\hline $\begin{array}{l}\text { kemampuan } \\
\text { pemecahan } \\
\text { masalah }\end{array}$ & 53 & $82,81 \%$ \\
\hline
\end{tabular}

Berdasarkan tabel 5 diatas Persentase ketuntasan siswa yaitu $82,81 \%$. Hal ini menunjukkan bahwa ketuntasan individu siswa telah mencapai batas minimum ketuntasan yaitu $75 \%$. Sehingga dapat disimpulkan bahwa produk yang dikembangkan efektif ditinjau dari kemampuan pemecahan masalah.

\section{Kajian Produk Akhir}

Setelah dilakukan serangkaian tahap pengembangan, diperoleh produk akhir yang berupa media pembelajaran matematika virtual berbasis TGT yang memuat standar kompetensi Memahami sifat-sifat kubus, balok, prisma, limas, dan bagian-bagiannya, serta menentukan ukurannya. Produk tersebut telah dinyatakan valid, praktis, dan efektif melalui analisis yang dilakukan terhadap data-data yang diperoleh.

Produk yang dikembangkan ini telah melalui proses validasi dan penilaian dengan melakukan revisi sebanyak 3 kali. media pembelajaran matematika virtual berbasis TGT ini juga ditujukan untuk meningkatkan kemampuan pemecahan masalah dalam belajar matematika. Kualitas produk yang dikembangakn sjuga dinyatakan sangat baik berdasarkan penilai ahli materi dan pembelajaran matematika, ahli media dan siswa sehingga layak digunakan untuk skala yang lebih besar. Produk ini dirancang sebagai media pembelajaran yang dapat digunakan guru untuk menyampaikan materi dikelas. Produk media pembelajaran matematika virtual berbasis TGT juga dapat diakses di http://labpmat.mercubuana-yogya.ac.id.

\section{SIMPULAN}

Berdasarkan hasil penelitian dan pembahasan diperoleh simpulan sebagai berikut: (1) Produk yang dikembangkan berupa media pembelajaran matematika virtual berbasis TGT materi pokok bangun ruang sisi datar. Media pembelajaran matematika memuat 4 tingkatan dengan permainan Uno Beam Magic, dimana permainan ini juga terdapat soal-soal yang harus dikerjakan untuk naik ke level berikutnya. Produk ini telah diujicobakan di SMP Negeri 1 Sedayu kabupaten Bantul dan dapat diakses atau diunggah melalui laman http://labpmat. mercubuana-yogya.ac.id sehingga layak digunakan dalam kegiatan pembelajaran dengan skala yang lebih luas; (2) Hasil pengembangan yang berupa media pembelajaran matematika virtual berbasis TGT dinyatakan sangat valid berdasarkan penilaian ahli materi dan pembelajaran, dan ahli media. Penilaian ahli-ahli tersebut secara konsisten mengkategorikan media pembelajaran matematika virtual berbasis TGT dalam kategori sangat valid; (3) Hasil pengembangan yang berupa media pembelajaran matematika virtual berbasis TGT dinyatakan praktis berdasarkan penilaian guru dan siswa. Penilaian guru dan siswa secara konsisten mengkategorikan multimedia pembelajaran matematika dalam kategori praktis; (4) Hasil pengembangan yang berupa media pembelajaran matematika virtual berbasis TGT dinyatakan efektif berdasarkan hasil tes kemampuan pemecahan masalah siswa. Dari hasil tes tersebut siswa secara konsisten menyatakan bahwa media pembelajaran matematika virtual berbasis TGT efektif ditinjau dari kemampuan pemecahan masalah. 


\section{DAFTAR PUSTAKA}

BSNP. (2006). Panduan penyusunan kurikulum tingkat satuan pendidikan jenjang pendidikan dasar dan menengah. Jakarta: Badan Standar Nasional Pendidikan.

Geisert, Paul G \& Mynga. 1995. Teachers, Computers and Curriculum: Microcomputers in the classroom. United State of America: Allyn \& Bacon.

Kemp, E. J. (1994). Instructional design: a plan for unit and course development (2nd ed). New York: Merril.

Lee, W., \& Owens, D. (2004). Multimedia based instructional design. San Fransisco: Preiffer.

Munir. 2008. Kurikulum Berbasis Teknologi Informasi dan Komunikasi. Bandung: Alfabeta.

Nieveen, N. (1999). Prototyping to Reach Product Quality dalam Plomp, T; Nieveen, N., Gustafson, K., Branch, R. M., \& van den Akker, J (eds). Design approaches and tools in education and training. London: Kluwer Academic Publisher.

Nurfitri R. (2015). Pengembangan Media Pembelajaran Uno Beam Magic Pada Materi Logika Matematika Untuk Siswa Kelas X SMA. Malang: Universitas Islam Malang.

Nuryadi. (2018). Prosiding Seminar Nasional Etnomatnesia Keefektifan Media Matematika Virtual Berbasis Teams Game Tournament Ditinjau Dari Cognitive Load Theory. Prosiding Seminar Nasional Etnomatnesia, 1(etnomatnesia), 110-119. Retrieved from

http://jurnal.ustjogja.ac.id/index.php/etno matnesia/article/view/2301/1264
Nuryadi, \& Khuzaini, N. (2016). Keefektifan Teams Game Tournament Ditinjau Dari Kemampuan Komunikasi Dan Pemecahan Masalah (Studi Eksperimen Pada SIswa Kelas VIII SMP Negeri 1 Seyegan). Mercumatika , 1(pendidikan matematika). https://doi.org/https://doi.org/10.26486/ mercumatika.v1i1.185

Pustekkom. (2004). Modul Serial Pelatihan Pengembangan Multimedia Interaktif. Jakarta: Pustekkom. Diknas.

Romi Satria Wahono. (2006). Aspek dan kriteria penilaian media pembelajaran. Diambil tanggal 23 April 2016 dari http://romisatriawahono.net/?p=170.

Slavin, R.E. (2008) Cooperatif learning. (Terjemahan Zubaedi). Bandung: Misan Nusa Media. (Buku asli diterbitkan tahun 2005).

Sugiman. (2013). Pengembangan Laboratorium Pendidikan Matematika Virtual:Adaptive E-Learning dan Cognitive Load Theory. Yogyakarta: Universitas Negeri Yogyakarta.

Sweller, J. (1999). Instructional Design in Technical Areas. Victoria, Australia: Australian Council for Educational Research.

Sweller, J. (2004). Instructional Design Consequences of an Analogy between Evolution by Natural Selection and Human Cognitive Architecture. Instructional Science, 32(1-2), 9-31.

Sweller, J. (2010). Element Interactivity and Intrinsic, Extraneous, and Germane Cognitive Load. Educational Psychology Review, 22(2), 123-138. 